\title{
Searching for the Golden Rule: A Case Study of Two White Novice Teachers' Beliefs and Experiences of Respect in Urban Schools
}

Shannon Audley

Smith College, saudley@smith.edu

Follow this and additional works at: https://scholarworks.smith.edu/edc_facpubs

Part of the Education Commons

\section{Recommended Citation}

Audley, Shannon, "Searching for the Golden Rule: A Case Study of Two White Novice Teachers' Beliefs and Experiences of Respect in Urban Schools" (2020). Education and Child Study: Faculty Publications, Smith College, Northampton, MA.

https://scholarworks.smith.edu/edc_facpubs/4

This Article has been accepted for inclusion in Education and Child Study: Faculty Publications by an authorized administrator of Smith ScholarWorks. For more information, please contact scholarworks@smith.edu 


\title{
Searching for the Golden \\ Rule: A Case Study \\ of Two White Novice \\ Teachers' Beliefs and \\ Experiences of Respect \\ in Urban Schools
}

Education and Urban Society 2020, Vol. 52(6) 872-903

(C) The Author(s) 2019

Article reuse guidelines: sagepub.com/journals-permissions DOI: 10.1 |77/00I3।245|9894984 journals.sagepub.com/home/eus

@SAGE

\section{Shannon Audley'}

\begin{abstract}
Student respect toward teachers is traditionally considered in terms of behavior or authority. Yet, because of cultural differences and historic oppression of marginalized students in schools, not all students express respect in ways in which teachers are familiar. Because of structural inequalities and individual differences, standard behavioral definitions of respect are insufficient to address how students and teachers actually experience respect in the classroom. Using a comparative case study design, this study examined two female White novice teachers' beliefs and experiences of student respect within a novel relational respect framework. Results identified that teachers' respect beliefs were based on notions of authority, while respect experiences reflected authority and relationshipbased respect. Importantly, these relationships were conceptualized as role model and friend-based respect. To help novice teachers balance their roles as both caring and authoritative figures, I propose that student respect should be thought of in relational, rather than behavioral, terms, and that teachers need to employ cultural competence when developing and maintaining their student-teacher relationships.
\end{abstract}

ISmith College, Northampton, MA, USA

\section{Corresponding Author:}

Shannon Audley, Department of Education and Child Study, Smith College, Morgan Hall, 37

Prospect Street, Northampton, MA 01063, USA.

Email: saudley@smith.edu 


\section{Keywords}

respect, student-teacher relationships, novice teachers, authority, case study, cultural competence

Across all grade levels, positive teacher-student relationships are necessary for educational success (Wentzel, 2010). However, fostering such relationships can be difficult for novice teachers. In addition to navigating racial, ethnic, and cultural differences (Crosnoe et al., 2004), novice teachers also struggle in defining their role within these relationships (Aultman et al., 2009; McBride \& Wahl, 2005; Pillen et al., 2013). One common struggle is how teachers' navigate their dual roles as authority figures and caring indivuidals (Aultman et al., 2009). Often novice teachers describe caring as important to enact in the classroom (Laletas \& Reupert, 2016) but simultaneously identify it as antithetical to authority (McLaughlin, 1991). In these cases, novice teachers dichotomize these roles and conclude that they can either be an authority figure or a caring indivuidal, but not both (Aultman et al., 2009; Weinstein, 1998). Although research addresses the importance of teachers caring for students (O'Connor, 2008; Schulz et al., 1997) and being an authoritative presence in the classroom (Wentzel, 2002), there is less guidance around how classroom caring and authority can positively intersect (cf. Brekelmans et al., 2002). Yet, these two seemingly disparate concepts come together in relational respect.

Respect is a fundamental component of positive interpersonal relationships (Frei \& Shaver, 2002). Although respect can be thought of as a caring response to the particularities of personhood (Dillon, 1992), it is not the same as an ethic of caring. In an ethic of caring, the teacher-student relationship includes engrossment, commitment, and a motivational shift from a focus on the teacher to a focus on the student (Noddings, 1992). In contrast, respect depends on the given, recognized, and accepted power differential between the persons in the relationship (Piaget, 1932/1952), and the behavioral expression and receipt of respect is influenced by the cultural backgrounds of each person ( $\mathrm{Li} \&$ Fischer, 2007). Thus, in addition to reflecting a balance between caring and authority, relational respect is also culturally cognizant.

In addition to considering the unique teacher-student relationship, structural inequality as well as cultural differences in students' backgrounds must be accounted for when examining respect among students and teachers (Audley \& Ginsburg, 2019). Within the school setting, however, researchers have not identified respect as relationship-based or culturally cognizant. Rather, previous research in the field has focused on respect as prescribed behaviors and automatic deference toward teachers' authority (Goodman, 
2009; Lickona, 2009). Given this, teachers' reliance on prescribed social conventions that reflect deference, such as listening or obeying, may not capture the myriad of ways that culturally diverse students in unique teacher-student relationships express respect (Audley \& Jovic, 2020; Audley-Piotrowski et al., 2008). In fact, research suggests that children's behavioral expressions of respect toward teachers are culturally dependent (Hsueh et al., 2005) and because the education system is built on the systematic oppression of marginalized populations, deference toward White authority by students of color, in particular, cannot be assumed (Ladson-Billings, 1996). Thus, teachers may miss opportunities of experiencing respect if non-authority respect behaviors go unrecognized.

Indeed, research suggests that teachers define and talk about respect in socially prescribed ways (Güngör et al., 2013); however, it is possible that in personal relationships with their students, they experience respect through a relational lens. Reframing respect as relationship-based rather than as prescribed behaviors may help teachers and administrators who serve schools with marginalized populations recognize how assumptions about power and privilege cloud interpretations of student behaviors and provide a framework for reinterpreting problematic student behaviors. As novice teachers find it difficult to merge authority and care into their roles, a gap between what teachers believe respect should be and what teachers recognize as respect in the classroom may further complicate their ability to foster and practice respectful relationships with students. As we know little beyond teachers' definitions of respect, this study sought to identify and contrast novice teachers' beliefs about, and experiences of, (relational) respect through their classroom interactions and relationships with their students.

To understand our framework of relational respect and provide context for our conclusions, our literature review will proceed as follows. First, I will present and deconstruct respect behaviors and expectations that are common in educational circles and argue that in contrast to these familiar notions, respect should be conceptualized within relationships. Then, I provide a framework for examining respect within teacher-student relationships, and highlight the importance of teacher cultural competence for respect within student-teacher relationships, before presenting the current study.

\section{Classroom Conceptions of Respect}

In the classroom, respect toward teachers is behaviorally characterized in two seemingly disparate ways: authority or caring (Goodman, 2009). Authoritybased respect is the most common conceptualization of respect within the educational context (Güngör et al., 2013; Lickona, 2009). Here, respect is 
identified through deferential behaviors; teachers should be automatically "be obeyed," or students should "follow the teacher's directions" because teachers are the authority.

In authority-based respect, teacher authority is not the product of successful interactions with students over time. Rather, the schooling institution automatically grants a teacher authority, regardless of the teacher's classroom effectiveness (Deutsch \& Jones, 2008; Goodman, 2009). This unexamined granting of teacher authority is problematic for two reasons. First, the very idea that institutions, such as schools, can grant authority, and by extension respect, is controversial. Because structural racism is inherent in the institution of schooling, the recognition of legitimate teacher authority is based on the historical privilege of White teachers (Ladson-Billings \& Tate, 1995), regardless of teacher deservingness or legitimacy (Obidah \& Teel, 2001). Black teachers, and other teachers of color, however, have their legitimate authority challenged by White students because of historical White privilege within the school system (Ladson-Billings, 1996; Rodriguez, 2008). Thus, legitimate authority granted through institutional status may translate unevenly due to the effects of structural inequality and institutional oppression. Second, because of their historical and concurrent experiences of oppression, students of color believe that authority and respect must be earned rather than automatically granted (Deutsch \& Jones, 2008; Hemmings, $2002,2003)$. Thus, depending on the race and ethnicity of the teacher and students, automatic deferential respect may not be an appropriate expectation. These accounts suggest that culture and ethnicity influence the perceived relation of authority and respect (Ford \& Sassi, 2014; Obidah \& Teel, 2001; Pace \& Hemmings, 2006). Because of this, a gap in respect beliefs and experiences may disproportionally affect teachers whose classroom approaches are rooted in traditional authority or have a diverse student body.

Unlike authority-based respect, mutuality-based respect, built on caring, works to disassemble all power structures among teachers and students. According to Nelsen and colleagues (2000), mutuality-based respect is "a two-way street" that "invites young people to see adults as people who need just as much nurturing and encouragement as they do" (p. 2). That is, teachers and students should similarily respect each other, including similiar levels of caring and empathy.

The deconstruction of power boundaries in mutuality-based respect an attractive alternative to authority-based respect, mutually-based respect is not without limitations. Mutuality-based respect requires both the teacher and the students to act as providers of care and support in the classroom. Expecting students to share the burden of caring for their teachers is not only developmentally inappropriate but may also be a risk factor for the teacher staying 
engaged in the profession. When a teacher's emotional expectations, such as students' caring, are not met, the teacher must engage in emotional labor (Chang, 2009), resulting in emotional exhaustion (Isenbarger \& Zembylas, 2006) and burnout (Kinman et al., 2011). Novice teachers are especially at risk because the first years of teaching are the ones that invoke the most potent emotions (Intrator, 2006; Liljestrom et al., 2007), and classroom inexperience can lead to unrealistic behavior expectations (Chang, 2009; Spilt et al., 2011). As such, the expectation of mutuality-based respect risks inappropriately burdening students and the longevity of teacher retention and well-being.

Although their differences are stark, authority- and mutuality-based respect are similar in one aspect: both are "things" that exist outside of relationships and can be identified through scripted behaviors. Their "thingness" suggests that certain expressions of respect can be overlooked or misrepresented if they are culturally situated (Hsueh et al., 2005; Li \& Fischer, 2007; Mann et al., 1994). For example, Hsueh and colleagues (2005), in a crosscultural study of 640 elementary school children from the United States and China, found U.S. children behaviorally identified showing respect to a teacher through obedience (i.e., "do[ing] what your teacher tells you to do") while Chinese children identified showing the teacher respect by fulfilling one's duty (i.e., "work[ing] hard on your school work"). This work suggests that if a teacher identified student respect solely through behaviors, it is likely that some intentional respect behaviors would go unacknowledged because of cultural differences in behavioral expectations of respect. Consequently, equating respect with classroom behaviors is insufficient to account for the cultural cognizance of respect, but a relational framework offers an improved approach for understanding respect.

\section{Theoretical Framework of Relational Respect}

Jean Piaget's $(1932 / 1952,1981)$ empirical work on respect among adults and children provides a framework for examining respect among teachers and students. Within this framework, respect is reflective of the cultural nature of respect expressions, the developmental age of the child, and, most importantly, the relationship in which respect occurs.

Interpersonal relationships are traditionally categorized through power relations as either horizontal (i.e., equal power relations; Rubin et al., 2006) or vertical (i.e., unequal power relations). Relationships among children or between adults of equal power stature are considered horizontal relationships. As teachers have status as adults, social position within the school, and the expectation for student obedience (Laupa et al., 1995; Laupa \& Turiel, 1993), 
student-teacher relationships are generally considered vertical relationships. However, there may be an exception: Adolescents often feel like they are equals to adults (Piaget, 1981) and are upset if their capabilities and adult responsibilities are not acknowledged (Rogoff, 2003).

\section{Respect Within Vertical Relationships}

For Piaget (1932/1952), unilateral respect is fostered within vertical relationships. In these relationships, respect is authority-directed. However, the behavioral expression of this respect is relationship specific and reflects the child's conception of moral evaluations. For example, in a relationship where admiration (based on a child's moral evaluation) is present, respect would motivate a child to behave obediently or imitatively, toward the adults' goals. This obedience is not forced or expected but serves as a compass to help children identify and imitate the behavior of community role models (Piaget, 1932/1952). However, it is also possible for a child to behave obediently because of fear of punishment rather than respect. What identifies the behavior as respectful is that the obedience or imitation is not coerced or forced. Respect occurs precisely because the child identifies moral value in the adult and recognizes the adult as a legitimate authority. Simply, it occurs because of the relationship between the child and adult.

In unilateral respect, respect can occur from both parties, but how respect is shown is not coordinated; it is expressed in different ways for different reasons. For example, in a student-teacher relationship, where the teacher's goal is for the student to learn, the student might express respect as working hard, enthusiastically engaging in tasks, shouting out answers, or asking clarifying questions, while the adult might express respect through validation or care. It is important to recognize that how respect is behaviorally expressed will depend on the social norms and cultural background of each person and the power differential within that unique relationship. For example, a student may show respect in a way that is reflective of their cultural community, such as shouting out an answer to a teacher's question in class; this, however, may not align with the cultural expectations of the teacher, who may expect respect to be behaviorally expressed as a student quietly raising their hand. Thus, because unilateral respect is not coordinated, it is possible that behavioral expressions of respect may be overlooked or misinterpreted in classrooms where teachers do not exhibit a high degree of cultural competence.

\section{Respect Within Horizontal Relationships}

For Piaget (1932/1952), mutual respect is fostered in horizontal relationships. Mutual respect is always reciprocal; both parties in the relationship express 
respect that is based on an understanding of the others' values and fostered through cooperation (Piaget, 1932/1952, 1981). Unlike unilateral respect, which is unidirectional or bidirectional, mutual respect is coordinated; both persons consider and respect each other as equals. Instead of social norms imposing themselves on the dyad from the outside or from one member to another, norms are co-constructed by each member with each member finding themselves in mutual service (Piaget, 1981).

\section{Respect and Cultural Competence}

Respect, because it relies on the recognition and coordination of social norms, must be given and received in ways that reflect cultural alignment ( $\mathrm{Li} \&$ Fischer, 2007). Thus, for a teacher to interpret respect in the classroom, the teacher must also be culturally competent within the school community. Culturally competent teachers "know enough about students' cultural and individual life circumstances to be able to communicate well with them" (Ladson-Billings, 2001, p. 5). However, "knowing" and "communication" is not enough; culturally competent teachers must also create caring studentteacher relationships that are sensitive to students' cultural backgrounds (Gay, 2010). Thus, teachers who are culturally competent are likely to foster and acknowledge respect that is culturally aligned within ethnically and economically diverse classrooms.

Although teacher cultural competence is associated with a host of student outcomes including academic achievement across all disciplines (Aronson \& Laughter, 2016), positive student-teacher relationships (Bowns, 2018; Gay, 2010), and positive ethnic-identity development (Byrd, 2016), teacher cultural competence is not a set of innate characteristics; rather, culturally competent knowledge, including skills and attitudes, are intentionally learned by teachers and implemented in classrooms. Unfortunately, few teacher-education programs are designed to meet the needs of a racially and ethnically diverse set of students (Ladson-Billings, 2000; Sleeter, 2017), and those that do focus on youth as "culturally deprived" or "culturally disadvantaged" (Ogbu, 1987). More so, the teaching profession is mostly comprised of White, female, and middle-class teachers (U.S. Department of Education, National Center for Education Statistics, 2018), and these teachers possess varying degrees of intercultural sensitivity (Westrick \& Yuen, 2007). The lack of intercultural sensitivity derives from a complex set of issues, including White teachers not understanding or identifying their own culture (Ladson-Billings, 2001), living monocultural lives (Nieto, 2000), downplaying White privilege (Leland \& Harste, 2005), and not questioning or recognizing the negative role that implicit ethnic bias has on teacher-student 
interactions and academic achievement (Brown, 2018; Peterson et al., 2016; Van den Bergh et al., 2010). The lack of recognition of implicit ethnic bias is especially detrimental to students, as it impacts not only their academic achievement but also their "personness." Brown (2018) suggests that implicit ethnic bias is ethnicity-specific and is a manifestation of a history of Western racial memory. Thus, how teachers respond to a student will depend on that student's ethnicity. For Blacks, in particular, Brown (2018) argues that historical racial discourse has constructed Black males as subhuman and that current practices in school and society, such as high suspension, expulsion, and special education for Black males, can be explained through the historically biased lens that Black males are feared and dangerous.

The implicit "othering" of ethnically diverse students by White teachers, in combination with lack of educational training in cultural sensitivity and unawareness of their own intersectional identity and the identity of their students, suggests that the present teaching profession is primed to misunderstand respect intentions in student-teacher relationships. Because the dominant U.S. educational system is built on the systematic oppression of marginalized peoples (Johnston, 2011; Roithmayr, 1999; Sadker \& Sadker, 1994), respect as deference toward White authority by students of color, in particular, cannot be assumed (Ladson-Billings, 1996). However, it is currently unknown whether teachers approach student respect in this manner.

\section{Overview of the Present Research}

Because the teacher-student relationship is often a vertical one, mutual respect may not be present in student-teacher relationships. However, as novice teachers struggle with balancing authority and caring in the classroom, it is possible that novice teachers might expect mutual respect from students. It is also possible that teachers might demand unilateral respect without the recognition of their authority. We do not know, however, how teachers think and experience respect within teacher-student relationships, and whether their expectations and experiences of respect misalign.

To understand the nuances of teachers' beliefs versus their experiences of student respect, I took a qualitative approach. Respect is a lived and relational concept; to account for different cultural perceptions of respect, I sought to highlight essential, underlying themes of experiences of respect while acknowledging individual and perceptual differences. Therefore, as I was interested in contextualized interactions and entanglements between multiple people and pieces of data, I used Yin's (1994) case study as a model for my methodology.

As Yin (1994) suggests, two research questions guided this study: 
Research Question 1 (RQ1): How do novice teachers describe their beliefs about student respect?

Research Question 2 (RQ2): How do novice teachers describe their experiences of student respect?

\section{Method}

A case study design was chosen for this study because it would allow a holistic approach to examining teachers' experiences of respect, would support a goal of identifying commonalities and unique features among teachers' beliefs and experiences (Stake, 1995), and be well-suited for real-world situations (Gray, 2009). Specifically, I chose to utilize an instrumental, comparative case study, as the study sought to understand the similarities and differences among participants as well as insight into one issue, respect (Yin, 1994).

\section{Data Collection}

As part of the study design, I included repeated, semistructured interviews, observations, field notes, and participant artifacts to add rigor and deepen the understanding of participants' experiences (Lincoln, 1995; Yin, 1994). In addition, because I am a former urban high school teacher, bracketing was used to remove personal prejudices from the entire research process (Tufford \& Newman, 2012). Personal, emotional connections to the initial research topic and design were noted through memoing and utilizing reflexive writing (Glaser, 1998) to help uncover researcher biases and negative feelings that may have surfaced during the interviews and observations.

Over a 4-month period in the spring, for each participant, I conducted four 60- to 90-min semistructured participant interviews, two classroom observations, and participant artifacts, including the creation of a concept map as graphical elicitation and participant journaling about respect and disrespect experiences.

\section{Data Analysis}

The final analysis was the result of triangulation across three information sources: interviews, field notes, and participant artifacts. Following Miles and Huberman (1994), I coded iteratively both during and following the data collection periods. Initially, I coded all interviews in two coding cycles: in vivo coding followed by axial and theoretical coding (Saldaña, 2012). In vivo coding uses the language of the participants to ground the analysis in the 
participant's perspectives; axial coding consolidates information taken from a wide variety of data sources, including observations, graphical elicitations, and participant journaling; and theoretical coding focuses on finding the essence of the experience (Saldaña, 2012). A research assistant used the codebook created during in vivo coding to independently code the interviews during the second coding cycle, then met with the author for consensus coding and triangulation (Lincoln \& Guba, 1985). After the second coding cycle, themes emerged from the identified codes in the portions of the interview, journaling, and concept map. Classroom observations were used to gain insight for interviews, to ask the participants to explain specific classroom observations, and to corroborate the level of classroom engagement, classroom management, and student efficacy. For triangulation purposes, the emerging themes were shown to the participants during the final interview for member checking.

\section{Participants}

I identified the two participants through purposeful sampling and maximum variation (Patton, 2014). For this study, two teachers, Ms. Sanford and Ms. Connor (pseudonyms), were chosen from a master's teacher education program for their similarities in personal background (e.g., White, middle class, female, graduate school), dedication to teaching in urban schools, novice teacher status, and the similarity of their schools in the mid-South. In addition, the teachers were also chosen for their stark differences in their classroom experiences, management styles, and teaching efficacy, as evidenced through self-report, observations, and school-level responsibilities. The content and grade levels of the specific classrooms differed (e.g., English vs. math, freshman vs. eighth grade), however, because respect among students and teachers may be related to relationship status rather than content, these differences better demonstrate the contextualized essence of respect.

Although the individual classrooms' contexts differed for each participant, their schools espoused similar characteristics: small private schools and student body composition (i.e., low social-economic status and African American student majority). Also, both schools were part of a larger parochial organization that spearheaded and approved faculty and administrative hiring and instituted similar discipline policies and character education programs for all its member schools. Notably, the chosen teachers reported similar values as their respective schools.

Ms. Sanford. Ms. Sanford was a 22-year-old White woman from a large city in the South. She received her undergraduate degree in mathematics 
education from a small liberal arts college, where she completed her teaching license and, at the time of the study, was in Year 2 of a master's program in teacher education. Professionally, Ms. Sanford was highly involved with her students and school community, serving as a soccer coach and faculty advisor of student clubs. Her classroom management skills were also strong; her principal encouraged other student-teachers and professional colleagues to observe her classroom teaching practices. She taught middle and high school mathematics. Self-reporting high teaching math self-efficacy, Ms. Sanford also self-reported that most of her students were on track to pass the course, and "mostly engaged" in class. Our observational data revealed strong congruence between Ms. Sanford's description of her classroom and her teaching. Ms. Sanford's classroom of focus was an average-level, eighth-grade math class comprised of 18 students (100\% African American, $61 \%$ female).

Ms. Connor. Ms. Connor was a 23-year-old White woman from a small city in the South. She received her undergraduate degree in English from a small liberal arts college and, at the time of the study, was in Year 2 of a master's program in teacher education. Professionally, Ms. Connor was highly involved with her students and school community, serving as a junior varsity cheerleading coach and attending school functions. However, her classroom management skills were weak; in the fall semester, the principal placed a novice male teacher to act as a disciplinarian in two of her most difficult classrooms. She taught middle and high school English. Self-reporting low self-efficacy for teaching English, Ms. Connor also self-reported that she felt her students were "not learning" and were "not engaged" in her classes. I noted strong congruence between our observational data and Ms. Connor's description of her classroom, where she struggled with classroom management and student engagement. Ms. Connor's classroom of focus was an average-level, ninth-grade English class comprised of 16 students (100\% African American, 25\% female). A male teacher was also present in this classroom; he did not, however, have a role in classroom instruction.

\section{Results and Discussion}

The themes identified fell into two broad contexts: the respect that teachers expected to get (beliefs about respect) and their reported experiences of respect with their students (actual respect experiences). In general, both teachers oscillated between describing what they thought should be happening in the classroom and what was happening in the classroom. As there is ample literature that suggests a large gap between novice teachers' expectations and actual classroom experiences (e.g., Fang, 1996), especially with 
regard to student behavior (Goldstein \& Lake, 2000), beliefs about respect were analyzed separately from actual respect experiences.

Descriptions about respect beliefs were drawn from questions about hypothetical respect experiences in the classroom and with students, or answers that were general and not taken or based on a specific experience (such as, "What does respect in the classroom mean to you") and participant concept mapping. Experienced respect descriptions were drawn from the teachers' descriptions of actual respect experiences in their classroom and with their students (such as, "Tell me about a time you experienced respect in the classroom"), observations, and participant journaling. As each teacher had a unique classroom and, therefore, unique respect experiences, teachers' voices highlight, explain, and structure the essence of their respect. Accordingly, portions of teacher responses are presented to illustrate their respect beliefs and experiences.

\section{Teacher's Beliefs About Respect: Commonalities}

Two interrelated respect belief themes consistently emerged throughout iterative processes: the belief that the teacher is the respected authority and that students show respect by fulfilling traditional White-middle class "student" roles and behaviors. In sum, both teachers believed that for respect to occur, the teacher needs to teach, be recognized as the authority, and the students need to learn, which occurs by listening to the teacher and engaging in the teacher's culturally preferred appropriate student roles and behaviors. Both teachers' expectations relied on their presumed institutional authority and the cultural assumptions of what "good students do."

Teacher as respected authority. When describing hypothetical examples about respect or beliefs about respect in the classroom, both teachers' responses focused on the role of the teacher and the role of the student in the classroom. These "roles" reflected the typical, hierarchical novice view of the classroom, where roles are clearly and professionally demarcated into teachers and learners, authority and students (Kaya et al., 2010). As Ms. Sanford succinctly stated, "It's a teacher's job to teach and a student's job to learn."

Both teachers noted the importance of the teacher as classroom authority and highlighted how classroom authority could be gained through classroom management skills. Ms. Connor explained, "I think there has to be a good level of discipline so students know not to cross lines with the teacher, an authority figure. And the teacher has to have control and organization in the classroom." Ms. Sanford concurred, "In terms of respect, they're [the 
teachers] there as authority figures ... I think the teacher's the authority to prevent disruption and deal with disruption if they occur."

The teachers' views closely align with authority-based respect, as respect is focused on recognizing the authority, and enforcing authority through discipline and control (Goodman, 2009). However, the teachers did not solely hold this view; they oscillated between being automatically and institutionally respected because of their status (Mann et al., 1994), and needing to prove that they were capable, legitimate authority figures before they could expect respect. Ms. Sanford described it as, "You [the teacher] have to prove you're an authoritative figure to the children before they will respect you, and before they put together the teacher as an authority rule."

This view of "earning" respect by being an authority figure is slightly reminiscent of adolescents' views of respect; adolescents do not believe that teachers should be given respect because they are the authority but, rather, that respect should be earned (Hemmings, 2002, 2003). However, rather than earning students' respect by strengthening a more personally aligned relationship that highlighted caring, both teachers thought that authority was earned through tightening the vertical aspects of the teacher-student relationships. Ms. Sanford emphasized, "If you don't have the authority and respect first ... they only see you as a friend ... they can't see you as authoritative at all."

In this way, both teachers assumed respect was embedded in their role as a teacher, and that being an effective teacher came from enforcing discipline. More so, their beliefs about the antithetical role of authority and caring echoed the literature on novice teacher views of student-teacher relationships (e.g., Aultman et al., 2009).

Students show respect by fulfilling traditional White-middle class "student" roles and behaviors. A second theme that emerged focused on students' classroom behaviors and roles, including quintessentially respectful students. For both teachers, a respectful student is one that does their work, participates in and prepares for class (e.g., answering questions and paying attention), and listens to the teacher. Ms. Connor described the quintessential respectful student:

A student who is always doing their work. Very motivated and a high achiever. So they tend to-because they're high achieving. Because they have more motivation in their work and academics. Because of that they're going to respect me when I tell them.

When asked to elaborate on specific types of behavior that the respectful student would engage in, Ms. Connor restated what she means by showing respect toward her authority: 
Respect with work attitude, I want to classify that as turning in homework ... What's really good is a lot of insightful questions. Because they show . . . they're trying to get their work done, they're trying to understand when I'm teaching. That's respect for me. Being prepared with materials and mentally and emotionally being prepared for class . . . Not to leave the classroom until I dismiss them ... Preparedness, having pen and paper ... and organization.

Ms. Sanford shared similar notions, and listed almost identical types of behaviors, including following the directives of the teacher, that the ideal respectful student would engage in during class.

[T]hey are trying to learn. You know they're listening and observing all the time ... When you listen and observe, you are following directions or the norms of the things you see happening. In class, if you are following the directions of the teacher, which are usually stay in your seat and listen, you are taking notes, you are doing your practice problems, you are doing the outside preparation like homework or working on a project or research . . . being responsible and bringing it to class, and having your supplies and things you need for school, coming on time, finishing your classes.

Teachers, in contrast, reciprocate respect by creating and enforcing a classroom environment conducive to learning. This authority-based respect may be one explanation why both teachers considered it a personal affront when a student disrupted the classroom environment. As Ms. Sanford described it, "This is my classroom and if you're not respectful in the classroom, you're disrespecting me, because you know what kind of environment I was trying to create, so it's personal, it's personally affecting me." Ms. Connor described students who disrupted the crafted classroom environment in any way were categorized as having a deficit attitude that indicated lack of personal care toward others.

They show an attitude that ruins ... it's a sign you don't care about another person's well-being and that's part of school and classroom ... is an obstacle for the job of the instructor whose part of the job is to protect the well-being of the students and when the students ignore the rules and the environment set up to keep them safe and happy ... when they disrupt that, it's disrespectful ... to the people trying to protect them.

These teachers' ideas about what it means to be a respectful student reflect behaviors and address personal characteristics that are associated with White, middle-class, "good students" (e.g., nice, listening, quiet; Wentzel, 1993). In essence, they described the respectful student as the quintessential, White, 
middle-class good student: passive, nonthreatening toward authority, and rule-abiding (Good, 1981; Good et al., 1987).

Overall, in the descriptions of respect beliefs, neither teacher mentioned any respect beliefs that were reminiscent of mutuality-based respect (Nelsen et al., 2000), nor any beliefs that were associated with mutual respect (Piaget, 1932/1952), which was surprising as both teachers repeatedly reported that they became involved in teaching because of their interest in social justice. However, the teachers did highlight the importance of respect as reciprocity through the student-teacher learning contract; the teacher will teach and the student will learn. This connected view of respect suggests that the teachers may have a rudimentary belief of unilateral respect (Piaget, 1932/1952), as they discussed the importance of students exhibiting the teacher-created norms (e.g., listening, completing homework) and acknowledged that they must also earn their students' respect. However, their views of respect, and their associated norms were not culturally competent or positive (e.g., "if student follows my directions then they will be successful") but negative ("if students don't listen that's disrespectful to me"). More so, the teachers believed that they earned respect through strict authority, rather than through personal caring, which is present in unilateral respect (Piaget, 1981). Taken together, their beliefs about respect suggest they see it as a thing that can be "given" or "taken away," rather than fostered within culturally competent student-teacher relationships. Although both teachers had similar beliefs about respect, their actual respect experiences were more varied, and included variations of unilateral respect and mutuality-based respect that reflected their attempts to address and balance authority and caring in their classrooms.

\section{Teachers' Experienced Respect: Commonalities and Disparities}

Three themes consistently emerged across the interviews, observations, and participant artifacts that focused on how teachers actually experienced respect: teacher as respected authority, teacher as respected role model, and teacher in the friend zone. Although both teachers reported experiencing authority-based respect, Ms. Connor reported rarely experiencing this type of respect, which was corroborated through observations. Ms. Sanford's authority as a teacher was present both in and out of the classroom. More so, although both teachers acknowledged that teacher as respected role model and teacher in the friend zone were types of experienced respect, only Ms. Sanford reported experiencing teacher as respected role model while only Ms. Connor reported experiencing respect as teacher in the friend zone. 
Teacher as respected authority: Commonalities. Both Ms. Sanford and Ms. Connor reported idealizing respect as teacher as respected authority as well as experiencing respect because of their authority. For example, when asked specifically about disciplinary problems, Ms. Sanford replies that it is not a problem:

They know not to argue. They don't even argue anymore. I'm just to the point where I'm like "Uh Frank, gum." And he'll—and I'll point to the trashcan and he'll spit it out. They realize that arguing with me is fruitless.

Yet, the experience of authority-based respect was not consistent across both participants. Although Ms. Connor reported that, at times, she had experienced this, it was not a common occurrence:

There have been lots of times so it's really hard to narrow it down. I often getwhen I have to correct a student for talking in class or not doing what they're supposed to be doing in class - they talk back. They don't say straight away "Yes ma'am." They don't do immediately what I tell them to do. It becomes a back and forth battle. They find it ... they think it's funny.

In explaining why they felt they deserved to be respected as authority, both teachers, when asked about their current classroom experiences, acknowledged that they felt they deserved respect because of cultural and personal expectations. This was highlighted in the conversations where both teachers recalled their experience of how they respected their teachers in adolescence. Although Ms. Sanford felt like the students acknowledged her authority in the classroom, she also elaborated on the difficulty of cultural experiences and expectations of respect for teachers:

In my school, you just took the teacher as authoritative role as granted. You walked in and you were going to do whatever the teacher said you were going to do. It wasn't questioned; they never had to prove it. And I'm saying thatmaybe the kids at my school when I was growing up, we were never directly disrespectful to the teacher's face, if they asked us to do something we would do it ... and here as a teacher ... . it's like you have to prove you're an authoritative figure to the children before they will respect you, and before they put together the teacher as an authority rule.

Navigating these cultural differences in how authorities should be respected was especially pertinent for Ms. Connor, as she stated that respect should be granted because of authority, "I was a child and they were an adult and I was brought up that there was a hierarchy. And their role automatically deserves 
that type of respect." It is interesting to note that both teachers felt that their students automatically respected their parents, and some teachers, in their school, and felt that the reason that they were not automatically respected as authority figures was because of their age, gender, and race. Ms. Connor noted that,

They're [the students] automatically going to respect those which are older. Their parents are usually older being authoritative figures, so being young that does not follow into that, and being White in a mostly Black student population, is also a disadvantage ... the other one is being female which has to do with the males more.

The teachers' descriptive experiences of their lack of automatic authority were not surprising, as they were reflective of the broader literature on authority in cross-ethnic relationships (Deutsch \& Jones, 2008) and competing discourses of respect (Hemmings, 2003), where respect is earned rather than automatically granted. More so, teachers' dismay of their lack of automatic authority reflects their acceptance of their historical privilege within the school system (Ladson-Billings \& Tate, 1995).

When asked to elaborate on why she was not "automatically respected," Ms. Sanford responded,

Most of my students have not had problems with Whites as far as I can tell, but they don't like them, you know, it's more like they want to be around people like them, it is what they are exposed to, they are not exposed to White people, and they are not used to listening to White people.

Ms. Sanford and Ms. Connor did not recognize that their expectation of respect as authority is based on White middle-class values and power, and reflects the structural inequality inherent in both society and the educational system. In excusing the students' lack of authority-based respect as "not used to listening to White people," both teachers reinforced hegemonic authority and recreated within their own classrooms the systems of oppression that both teachers set out to dismantle. In both of these cases, the teacher's expectation of respect was not culturally competent and created a cultural chasm of respect expectations that unintentionally reinforced historical oppressions.

Fortunately, although both teachers described the importance of authority, they both mentioned that the role of the teacher is not simply about being the authority, but also of teaching the students how "to act as people," which requires the teachers to navigate a more personal, caring role (albeit 
possibly laden with cultural expectations), described in more detail in the next section.

Teacher as respected role model versus teacher in the friend zone: Disparities. Although neither teacher acknowledged the importance of respect on a more personal, caring level when talking about beliefs about respect, both teachers reported experiencing a more personalized, relationship-based respect, which was similar to an ethic of care in the student-teacher relationship (Gomez et al., 2004). These more mutually-based respect experiences, however, were never described as part of the larger classroom interactions but, rather, only occurred with individual students, often happening before class started or in after-school activities. The "type" of relational respect experienced depended on how the teacher navigated her authority in conjunction with expressing care: either respected role model or respect in the friend zone.

Although these respect experiences are both described as "more mutual," respected role model reflected a balance of caring and authority in the relationship and reflected a relational respect; however, respect in the friend zone reflected a caring-based respect that was undermined due to the absence of authority. In both of these more mutual respects, it was unclear whether or not the teachers identified a culturally specific way that the respect needed to be shown, as with the authority-based respect. Rather, the teachers seemed to loosely coordinate or, at least, positively interpret students' behaviors when these interactions were more personal and did not relate directly to schooling.

Ms. Sanford's role model respect. Ms. Sanford, who was a consistently effective teacher and felt that her authority was respected, experienced role model respect, an admiration- rather than fear-based unilateral respect that occurred not because of authority, but in conjunction with her authority and personal characteristics that connected her with her students. Although Ms. Connor mentioned role model respect in one interview, she did not describe experiencing this type of respect. Role model respect was described as a natural extension of scholastic teaching duties; teachers not only teach content, but also social conventions, as Ms. Sanford elaborated, "Teaching is academic, but we also have to teach them social rules, we also have to teach them care for each other and we do that by modeling, also by showing them that you can joke around, have fun."

Although similar to mutuality respect as described by Nelsen and colleagues (2000), where the teacher exhibits a human connection with the student, this type of respect is not relational mutual respect or mutuality-based 
respect, because the view of the student as subordinate is not abandoned. Ms. Sanford described it as a balance of what it means to actually educate a child:

I would go more along the lines of role model and you're teaching the students to be people. How they're supposed to behave outside of school but then you're also teaching them skills they'll need to be successful as well. So I think role model is the best way to describe that because if you are using these skills and showing them that it's important, and they can tell that you think something is important, then they will think it's important and will want it as well ... They want to emulate you.

Yet, while the personal relationship and caring is evident, as caring is modeled, there is still clearly a power distinction between the teacher and the student; the student wants to "emulate" the teacher. This emulation is found in unilateral respect, because it is not respect based on authority, but given to an authority who cares (Piaget, 1932/1952). Ms. Connor had similar notions of the role of the teacher as a role model when she added,

I think a big part of keeping — gaining respect, as a teacher is to make sure that you're modeling it for a student. Modeling it by showing them how you want respect because if the students don't know how you want respect, it's hard to gain it ... They're more likely to have respect when you want it and the kind that you want ... Not all of it lies on the student; some is on the teacher.

The teacher as a role model is one way that both teachers suggested navigating the dichotomy of authority and being a caring person. Both teachers mentioned that as long as the teacher is being treated with a level of respect and is still maintaining her position as the authority figure, role modeling is not detrimental to the way that the students perceive the teacher. As Ms. Sanford noted,

I feel like I enjoy it when they say those comments like, "I like your yellow shirt" because they see me more as a person than "This is a robot up here" ... It makes me feel like they see me as someone they can relate to if they like something that I have.

There is a fine line between being a role model and being perceived as a friend, however, and both teachers acknowledge the existence of such a line. When asked where she saw the personal line between not acknowledging the authority role versus acknowledging role model, Ms. Sanford replied,

I mean, when they're saying things [compliments] like that, it takes me out of the authoritative role. But at the same time they're complimenting me, so 
they're maintaining a level of respect by making the comment. I don't know; they're not - I feel like ... since my authoritative role is there, when they make these comments which take me out of the authoritative role, I don't feel like my authority is in jeopardy.

Ms. Connor mentioned the importance of context when navigating the potential loss of authority through more personal interactions:

I guess it has to be used in the context ... If they know I'm in the mode of trying to get work done or I'm kind of in a more relaxed attitude, we can take that time to talk on the level, but when I'm trying to stop them from being bad or get them to do something that needs to be done, they get it.

This view of respect, again, reflects the importance of considering respect within a reciprocal relationship, but one where the teacher has an authority that is accepted. Although the teachers framed their explanation as one of imparting "social rules," with one exception from Ms. Sanford about being asked to coach soccer, the examples focused on personal style, rather than cultural norms about how to behave. It seems that role model respect may be a way for teachers to form a personal connection with their students without losing a sense of their authority, as well as find commonalities across cultural differences, as long as their authority is gained first. If authority is not gained first, then anything remotely personal may shift into what Ms. Sanford described as respect in the friend zone:

I feel if you don't have the authoritative role first, you can't make those transitions, and you are never going to get them to listen to you. If they see you more as a peer, it's kind of like boyfriend girlfriend relationships, like you have a boy that is a friend; you can't get out of the friend zone. It is kind of like that for a teacher friend, if the kids see you as a friend first, they are never going to see you as a teacher.

Ms. Connor's respect in the friend zone. Ms. Connor, who was neither consistently effective nor a respected authority, experienced friend-zone respect, a heavily care-based respect where students acknowledged her as a peer as opposed to an authority. Although Ms. Sanford acknowledged as having seen friend-zone respect in some of her colleagues' interactions with students, she did not report experiencing this type of respect.

Teachers who were described as "in the friend zone" by the participants were those who attempted to form caring relationships with their students before establishing their authority. However, teachers who were more 
personable after establishing an authority did not necessarily experience a loss in authority and in unilateral, role model respect. Ms. Sanford explains,

I think that gaining the authority and respect comes first because in my experience, I notice that if you don't have the authority and respect first and then they only see you as a friend and someone who cares about them or wants to help them or wants to have fun then that's the only way they see you and they can't see you as authoritative at all. But the other way around when they see you as a authoritative figure, they see you as a teacher first, like a teacher is supposed to be seen as someone who is going to teach you, someone who is going to make you learn you are really going to grow in the class.

Ms. Connor agreed with this view of authority before friendship, but unlike Ms. Sanford, felt comfortable letting her guard down with her students.

I appreciated the response I got from letting my guard down and I call it respectful because they didn't take advantage of me-I feel like, typically, their typical behavior to a teacher letting their guard down is they cross the line. And this time they didn't. And by crossing the line, I mean not looking at the teacher-not speaking to the teacher in the way they would speak to ... yes they are a little more lax with the teacher but they're not crossing a line with how they would with the peers. Like how they would speak with their peers that they wouldn't to a teacher. But there's still a comfort level there.

This "letting down of the guard," however, also seemed to correspond with her students' failure to acknowledge her authority like when they refer to her by her first name:

They think it's hilarious to know my first name and say it out loud to me in the hallway or the classroom. Personally that's not an offense I'm going to hold a grudge against and I'm not going to berate a student about it. I'll correct them but that's a big one.

Although Ms. Connor repeatedly noted that the "peer like" interactions that she encountered with her students, such as apologizing to them when she made a mistake, supported a positive classroom climate, these interactions also left her feeling disrespected.

I feel like students want to view me as a peer sometimes or just they wanna be more laid-back with me and they may struggle with seeing me as an adult or a dominant figure. And I have a very ... I wouldn't call myself submissive but I'm not ... the word isn't coming to me. But I'm not a person who is good at demanding respect. 
Ms. Connor almost described her lack of respect as a personal character flaw. She associated respect with dominance and reasons that it was her nondominating personality, not her lack of classroom management skills, that explained her students' disrespect. When asked to further speculate why her students do not respect her, Ms. Connor replied,

I see myself lacking confidence. I'm struggling with the word I want to use; I'm trying to think. It's not intimidating ... I'm not going to go up to a person and saying, "I need this," I'm like "May I have this," that's how I act with people.

Ms. Connor translated her lack of demandingness into a lack of respect. This is an important point because both teachers' interpretations of experienced respect are based on a deservingness model. Respect is primarily deserved because the teacher is the authority, and once the teacher is an authority, she can be caring, but if the teacher is not the authority, then she does not deserve respect, regardless of her level of care. In this case, Ms. Connor downplayed her students' responses to her caring and modeling caring behavior as important for the process of respect; instead, she focused on her lack of authority. For her then, authority was key for respect; caring without recognition of authority does not promote respect.

\section{General Discussion}

The National Commission on Teaching and America's Future estimates that roughly $30 \%$ of novice teachers leave after 3 years in the classroom, and $46 \%$ leave within 5 years; these rates of attrition are higher in urban school districts (National Commission on Teaching and America's Future [NCTAF], 2003). Urban schoolteachers reported leaving the profession, in part, because of lack of student respect (Gonzalez et al., 2008; National Education Association [NEA], 2008). But what do teachers mean by lack of student respect? How can we help combat teacher turnover in ethnically and economically urban school districts without first understanding teachers' lived experiences of respect in the classroom?

This study examined the respect beliefs and experiences of two White, secondary, novice teachers who taught in an urban, ethnically diverse school setting. The two teachers' beliefs about respect highlighted the importance of authority behaviors, yet their respect experiences reflected caring and authority, albeit hegemonic at times, within student relationships. This discrepancy between teachers' beliefs and their respect experiences seemed to create 
disequilibrium in how they navigated and approached their roles as teachers and negotiated the acknowledgment of being respected in their classrooms.

The literature suggests that authority is not antithetical to cooperation and caring; however, because the struggle for classroom authority is emphasized in the first few years of teaching, these novice teachers may have placed more emphasis on developing classroom authority rather than cultivating cooperation (Brekelmans et al., 2005) or reciprocal caring. This emphasis may have been necessary as students who describe their teachers as experienced and authoritative are more successful students (Wentzel, 2002). However, the focus on authority may come at a potential cost: Positive learning outcomes for students in secondary classrooms rely on more communicative and proximal, rather than distal, teacher-student relationships (Wubbels \& Brekelmans, 2005), and hegemonic, unearned authority undermines achievement in ethnically diverse classrooms (Ford \& Sassi, 2014).

Both Ms. Sanford and Ms. Connor take their own experiences (and expectations) of authority-based respect for granted. In urban, ethnically diverse schools, such as the ones where both participants worked, adolescent students are often disenfranchised because of racism embedded within the institutional structure (Hemmings, 2003). In these cases, respect for authority, if the authority is hegemonic, must be earned rather than given (Deutsch \& Jones, 2008; Hemmings, 2002). When teachers fail to see the importance of earning their students respect, teachers can recreate the structural inequality and oppression that youth experience within their own classrooms. By not employing culturally competent approaches to student-teacher relationships and classroom expectations, teachers not only reinforce the ethnic achievement gap (Peterson et al., 2016; Van den Bergh et al., 2010) but prime the school-to-prison pipeline (McNeal, 2016; Simson, 2014). When it comes to respect, teachers must consider not only the cultural context of the school and their students, but the history of oppression that their students have experienced as well.

Adolescents also report that they should be respected as people, as well as learners, (Douglas et al., 2008), which neither teacher explicitly acknowledged. Indeed, a failure to understand their students' ethnic and cultural backgrounds likely implicitly influenced their inability to think about their students as people. This lack of cultural competency, however, can lead to potentially grave outcomes. If students do not feel respected, they will not show respect for the teacher (Hemmings, 2003), which may reinforce a cycle of disrespect (Audley \& Ginsburg, 2019). These two explanations help support why both teachers struggled to integrate the intersections of respect expectations and experiences. 
Although respect in the friend zone reflected the importance of caring in respect, it seems evident that being placed in the "friend zone" was associated with classroom management difficulties and loss or lack of acknowledged authority. This may suggest that mutuality-based respect or mutual respect, because of its reliance on a more horizontal power structure, may be difficult for novice teachers to effectively navigate. As seen from this study, it may also be a negative as well as a positive experience for some teachers, as caring was described as reciprocal, but undermined authority that was necessary to manage a classroom (Wubbels \& Brekelmans, 2005). Given these findings and the connections among teacher burnout, exit, and respect, we suggest that respect be considered a relational process in student-teacher relationships, where teachers can focus on developing respect through being a caring authority figure.

\section{Implications}

Respect is relational. For both teachers in this study, their actual experiences of respect were nuanced and emerged from insights reflected on and created from their larger teacher-classroom and teacher-student relationships, rather than on explicit behavioral expectations. This is a form of relational pedagogy (Bingham \& Sidorkin, 2004) where human relations, rather than behaviors, affect teaching and learning. For teachers to be able to consider a class's or an individual's intentionality, they must go beyond the signs of respect, such as hand-raising, and think about respect not as a "thing" to be gained or lost in moments, but as developed over time. Understanding students' perspectives, at the classroom and individual level, then, can only be gained through the development of teacher-student relationships.

Novice teacher's struggles with respect may not be derived from what actually occurs in the classroom, per se, but in the gap between their experiences versus their expectations. If respect is a relational process, then the students' own perspectives must be considered; teachers should not rely on their own expectations, but consider developing the teacher-student relationship through balancing both caring and authority. This shift suggests that both teachers and teacher educators need to reconsider how authority is portrayed, and acknowledge that it, too, is part of a relational process, and one that has to be earned each year rather than automatically extended from the school's institutional and hegemonic authority.

Helping teachers identify relational respect values. Teachers can learn how to identify relational respect values in a variety of ways. In this study, the two teachers reported the most extensive experiences of relational respect 
as having occurred outside of the classroom-as coaches, and leaders of extracurricular activities. These non-classroom experiences may allow teachers to see authority as earned and because there are no official teacher and student roles, caring can be incorporated more easily into these relational settings. I acknowledge that not all teachers are qualified or have time to engage in coaching or participate in student extracurricular activities. However, teachers can also use reflection techniques, like keeping a respect journal, to help them reflect and identify what behaviors and relationships they value as respectful in the classroom.

In addition, it is important for novice teachers to expect discrepancies between their own and their students' respect beliefs, as respect is cultural in origin and context specific (Hsueh et al., 2005; Li \& Fischer, 2007; Mann et al., 1994). However, teachers can possibly reframe respect beliefs and experiences through classroom negotiations (Audley \& Jovic, 2020; Brown, 2004; Gay, 2010) and instigating an ethic of care in the classroom (Owens \& Ennis, 2005). In a classroom where the teacher and the students discuss what it means to respect and what behaviors illustrate showing respect, the likelihood of misinterpreting disrespectful behaviors or underreporting respectful behaviors may decrease. Yet, how this is actually done in practice, and whether teachers change their own actual expectations of respect has not been explored. More so, teachers should realize that it is possible to show a caring, more personal side, without undermining their authority in studentteacher relationships (Van Tartwijk et al., 2009; Wubbels \& Brekelmans, 2005), although the actual classroom implementation of these practices depends on the cultural background of the teacher and their students (Ford \& Sassi, 2014).

Finally, the findings of this study have implications for supporting novice teachers in the classroom. Novice teachers would benefit from thinking about and discussing their broader expectations about navigating personal and professional student-teacher relationships, especially with a focus on naïve beliefs and expectations about what classroom authority means. Often, novice teachers need extra support in navigating the humanness of their classrooms, yet the human aspects of teachers are often overlooked in professional development opportunities. Novice teachers also need more support and training in cultural competency to help them develop positive, caring relationships with an ethnically and economically diverse set of students without reinforcing stereotypes or strengthening the ethnic achievement gap.

\section{Limitations, Future Research Considerations, and Conclusion}

Given what I presented here, further research should focus on the coordination and creation of respect and disrespect values in the classroom over the 
course of the school year, and examine ways in which teacher beliefs and negotiations about the student-teacher relationship, White middle-class values, and implicit bias influence respect expectancies in the classroom. Understanding and accepting respect from a cultural perspective may potentially decrease the rates of disrespect-related teacher burnout in ethnically and economically diverse schools.

Although this study provides a limited glimpse into the ideas and perceptions of respect in two classrooms, it suggests that novice teachers' respect expectations may focus exclusively on authority, which may reinforce implicit bias, and delay the formation of personal relationships that support the caring side of unilateral respect, which may potentially undermine a positive classroom climate (Nelsen et al., 2000; Patrick et al., 2011) and a culturally responsive classroom (Gay, 2010). This struggle surrounding authority in student-teacher relationships and navigating how authority status is gained, especially in ethnically and economically diverse urban schools, deserves further consideration and study, especially because novice teachers report difficulty in navigating classroom relationships (Aultman et al., 2009), and they receive little to no training in teacher education programs for the human aspects of teaching, such as moral development, ethical care (Velasquez et al., 2013), and cultural competency (Farr et al., 2005; Nieto, 2000).

Although some may argue that attention to the human aspects of teaching is not appropriate given the intense focus in educational circles on standardized testing and academic achievement, it is important to recognize that the human factors of the classroom inherently influence academic achievement, especially for academically at-risk students (Spilt et al., 2011; Williford et al., 2013) and ethnically diverse students (Peterson et al., 2016; Van den Bergh et al., 2010). Given this, understanding and promoting the role of respect in the classroom is essential in the present educational landscape, because helping novice teachers form positive student-teacher relationships and navigate their authority may encourage teachers to soldier on through their tremulous early years in the classroom and may help discourage novice teachers from unintentionally reinforcing structural inequality within their classrooms.

\section{Declaration of Conflicting Interests}

The author(s) declared no potential conflicts of interest with respect to the research, authorship, and/or publication of this article.

\section{Funding}

The author(s) received no financial support for the research, authorship, and/or publication of this article. 


\section{ORCID iD}

Shannon Audley (iD https://orcid.org/0000-0003-3970-9503

\section{References}

Aronson, B., \& Laughter, J. (2016). The theory and practice of culturally relevant education: A synthesis of research across content areas. Review of Educational Research, 86(1), 163-206. https://doi.org/10.3102/0034654315582066

Audley, S., \& Ginsburg, J. L. (2019). Caring as an authoritative act: Re-thinking respect for students and teachers. In K. Daniels \& K. Billingsley (Eds.), Creating caring and supportive educational environments for meaningful learning (pp. 154-182). IGI Global.

Audley, S., \& Jovic, S. (2020). Making meaning of children's social interactions: The value tensions among school, classroom, and peer culture. Learning, Culture, and Social Interaction, 24. https://doi.org/10.1016/j.lcsi.2019.100357

Audley-Piotrowski, S., Hsueh, Y., \& Cohen, R. (2008). Respect: A developmental perspective. Academic Exchange Quarterly, 12(3), 207-211.

Aultman, L. P., Williams-Johnson, M. R., \& Schutz, P. A. (2009). Boundary dilemmas in teacher-student relationships: Struggling with "the line." Teaching and Teacher Education, 25(5), 636-646. https://doi.org/10.1016/j.tate.2008.10.002

Bingham, C., \& Sidorkin, A. M. (Eds.). (2004). No education without relation. Peter Lang.

Bowns, J. M. (2018). Effective teachers building relational trust with diverse students to improve reading achievement [Doctoral dissertation]. Montana State University.

Brekelmans, M., Wubbels, T., \& den Brok, P. (2002). Teacher experience and the teacher-student relationship in the classroom environment. In Studies in educational learning environments: An international perspective (pp. 73-100). https:// doi.org/10.1142/9789812777133_0004

Brekelmans, M., Wubbels, T., \& van Tartwijk, J. (2005). Teacher-student relationships across the teaching career. International Journal of Educational Research, 43(1), 55-71. https://doi.org/10.1016/j.ijer.2006.03.006

Brown, A. L. (2018). From subhuman to human kind: Implicit bias, racial memory, and Black males in schools and society. Peabody Journal of Education, 93(1), 52-65. https://doi.org/10.1080/0161956X.2017.1403176

Brown, D. F. (2004). Urban teachers' professed classroom management strategies reflections of culturally responsive teaching. Urban Education, 39(3), 266-289. https://doi.org/10.1177/0042085904263258

Byrd, C. M. (2016). Does culturally relevant teaching work? An examination from student perspectives. Sage Open, 6(3), 1-10.

Chang, M. L. (2009). An appraisal perspective of teacher burnout: Examining the emotional work of teachers. Educational Psychology Review, 21(3), 193-218. https://doi.org/10.1007/s10648-009-9106-y

Crosnoe, R., Johnson, M. K., \& Elder, G. H. (2004). Intergenerational bonding in school: The behavioral and contextual correlates of student-teacher 
relationships. Sociology of Education, 77(1), 60-81. https://doi.org/10.1177 /003804070407700103

Deutsch, N.L., \& Jones, J.N.(2008). "Show me an ounce of respect”: Respectand authority in adult-youth relationships in after-school programs. Journal of Adolescent Research, 23(6), 667-688. https://doi.org/10.1177/0743558408322250

Dillon, R. S. (1992). Respect and care: Toward moral integration. Canadian Journal of Philosophy, 22(1), 105-131. https://doi.org/10.1080/00455091.1992.10717273

Douglas, B., Lewis, C. W., Douglas, A., Scott, M. E., \& Garrison-Wade, D. (2008). The impact of White teachers on the academic achievement of Black students: An exploratory qualitative analysis. Educational Foundations, 22(1-2), 47-62.

Fang, Z. (1996). A review of research on teacher beliefs and practices. Educational Research, 38(1), 47-65. https://doi.org/10.1080/0013188960380104

Farr, B. P., Sexton, U., Puckett, C., Pereira-León, M., \& Weissman, M. (2005, September). Study of availability and effectiveness of cultural competency training for teachers in California: Final report. WestEd.

Ford, A. C., \& Sassi, K. (2014). Authority in cross-racial teaching and learning (re) considering the transferability of warm demander approaches. Urban Education, 49(1), 39-74. https://doi.org/10.1177/0042085912464790

Frei, J. R., \& Shaver, P. R. (2002). Respect in close relationships: Prototype definition, self-report assessment, and initial correlates. Personal Relationships, 9(2), 121-139. https://doi.org/10.1111/1475-6811.00008

Gay, G. (2010). Culturally responsive teaching: Theory, research, and practice. Teachers College Press.

Glaser, B. G. (1998). Doing grounded theory: Issues and discussions. Sociology Press.

Goldstein, L. S., \& Lake, V. E. (2000). "Love, love, and more love for children": Exploring pre-service teachers' understandings of caring. Teaching and Teacher Education, 16(8), 861-872. https://doi.org/10.1016/S0742-051X(00)00031-7

Gomez, M. L., Allen, A. R., \& Clinton, K. (2004). Cultural models of care in teaching: A case study of one pre-service secondary teacher. Teaching and Teacher Education, 20(5), 473-488. https://doi.org/10.1016/j.tate.2004.04.005

Gonzalez, L., Brown, M. S., \& Slate, J. R. (2008). Teachers who left the teaching profession: A qualitative understanding. The Qualitative Report, 13(1), 1-11.

Good, T. L. (1981). Teacher expectations and student perceptions: A decade of research. Educational Leadership, 38(5), 415-422.

Good, T. L., Slavings, R. L., Harel, K. H., \& Emerson, H. (1987). Student passivity: A study of question asking in K-12 classrooms. Sociology of Education, 60(3), 181-199. https://doi.org/10.2307/2112275

Goodman, J. F. (2009). Respect-due and respect-earned: Negotiating student-teacher relationships (EJ855755). Ethics and Education, 4(1), 3-17. ERIC database.

Gray, D. E. (2009). Doing research in the real world. SAGE.

Güngör, S., Aydın, İ., Memduhoğlu, H. B., \& Oğuz, E. (2013). Respect in principal-teacher relations at primary schools in Turkey. International Journal of Qualitative Studies in Education, 26(10), 1349-1372. https://doi.org/10.1080/0 9518398.2012 .724464 
Hemmings, A. (2002). Youth culture of hostility: Discourses of money, respect, and difference. International Journal of Qualitative Studies in Education, 15(3), 291307. https://doi.org/10.1080/09518390210122836

Hemmings, A. (2003). Fighting for respect in urban high schools. Teachers College Record, 105(3), 416-437. https://doi.org/10.1111/1467-9620.00245

Hsueh, Y., Zhou, Z. K., Cohen, R., Hundley, R. J., \& Deptula, D. P. (2005). Knowing and showing respect: Chinese and U.S. children's understanding of respect and its association to their friendships. Journal of Psychology in Chinese Societies, $6(2), 89-120$.

Intrator, S. (2006). Beginning teachers and emotional drama in the classroom. Journal of Teacher Education, 57(3), 232-239.

Isenbarger, L., \& Zembylas, M. (2006). The emotional labour of caring in teaching. Teaching and Teacher Education, 22(1), 120-134. https://doi.org/10.1016/j. tate.2005.07.002

Johnston, M. (2011). From exclusion to integration: The N.A.A.C.P.'s legal campaign against educational segregation. Chapman University Historical Review, 3(1), 23-34.

Kaya, S., Lundeen, C., \& Wolfgang, C. H. (2010). Discipline orientations of preservice teachers before and after student teaching. Teaching Education, 21(2), 157-169. https://doi.org/10.1080/10476211003632475

Kinman, G., Wray, S., \& Strange, C. (2011). Emotional labour, burnout and job satisfaction in UK teachers: The role of workplace social support. Educational Psychology, 31(7), 843-856. https://doi.org/10.1080/01443410.2011.608650

Ladson-Billings, G. (1996). Silences as weapons: Challenges of a Black professor teaching White students. Theory into Practice, 35(2), 79-85.

Ladson-Billings, G. (2000). Fighting for our lives: Preparing teachers to teach African American students. Journal of Teacher Education, 51(3), 206-214.

Ladson-Billings, G. (2001). Crossing over to Canaan: The journey of new teachers in diverse classrooms. Jossey-Bass.

Ladson-Billings, G., \& Tate, W. F. (1995). Toward a critical race theory of education. Teachers College Record, 97(1), 47-58.

Laletas, S., \& Reupert, A. (2016). Exploring pre-service secondary teachers' understanding of care. Teachers and Teaching, 22(4), 485-503. https://doi.org/10.108 0/13540602.2015.1082730

Laupa, M., \& Turiel, E. (1993). Children's concepts of authority and social contexts. Journal of Educational Psychology, 85(1), 191-197. https://doi. org/10.1037/0022-0663.85.1.191

Laupa, M., Turiel, E., \& Cowan, P. A. (1995). Obedience to authority in children and adults. In M. Killen \& D. Hart (Eds.), Morality in everyday life: Developmental perspectives (pp. 131-165). Cambridge University Press.

Leland, C. H., \& Harste, J. (2005). Doing what we want to become: Preparing new urban teachers. Urban Education, 40(1), 60-77.

Li, J., \& Fischer, K. W. (2007). Respect as a positive self-conscious emotion in European Americans and Chinese. In J. L Tracy, R. W. Robbing, \& J. P. Tangney (Eds.), The self-conscious emotions: Theory and research (pp. 224-242). Guilford Press. 
Lickona, T. (2009). Educating for character: How our schools can teach respect and responsibility. Bantam.

Liljestrom, A., Roulston, K., \& deMarrais, K. (2007). "There is no place for feeling like this in the workplace": Women teachers' anger in school settings. In P. A. Schutz \& R. Pekrun (Eds.), Emotions in education (pp. 275-292). Elsevier.

Lincoln, Y.S.(1995). Emerging criteria for quality in qualitative and interpretiveresearch. Qualitative Inquiry, 1(3), 275-289. https://doi.org/10.1177/107780049500100301

Lincoln, Y. S., \& Guba, E. G. (1985). Naturalistic inquiry. SAGE.

Mann, L., Mitsui, H., Beswick, G., \& Harmoni, R. V. (1994). A study of Japanese and Australian children's respect for others. Journal of Cross-Cultural Psychology, 25(1), 133-145. https://doi.org/10.1177/0022022194251008

McBride, M. C., \& Wahl, S. T. (2005). "To say or not to say”: Teachers' management of privacy boundaries in the classroom. Texas Speech Communication Journal, $30(1), 8-22$.

McLaughlin, H. J. (1991). Reconciling care and control: Authority in classroom relationships. Journal of Teacher Education, 42(3), 182-195. https://doi. org/10.1177/002248719104200304

McNeal, L. R. (2016). Managing our blind spot: The role of bias in the school-toprison pipeline. Arizona State Law Journal, 48, 285-311.

Miles, M. B., \& Huberman, A. M. (1994). Qualitative data analysis. SAGE.

National Commission on Teaching and America's Future. (2003). No dream denied: A pledge to America's children.

National Education Association. (2008). Why they leave. http://www.nea.org/ archive/12630.htm

Nelsen, J., Lott, L., \& Glenn, H. S. (2000). Positive discipline in the classroom: Developing mutual respect, cooperation, and responsibility in your classroom. Random House.

Nieto, S. (2000). Placing equity front and center: Some thoughts on transforming teacher education for a new century. Journal of Teacher Education, 51(3), 180-187.

Noddings, N. (1992). The challenge to care in schools. An alternative approach to education. Teachers College Press.

Obidah, J. E., \& Teel, K. M. (2001). Because of the kids: Facing racial and cultural differences in schools. Teachers College Press.

O'Connor, K. E. (2008). "You choose to care": Teachers, emotions and professional identity. Teaching and Teacher Education, 24(1), 117-126. https://doi. org/10.1016/j.tate.2006.11.008

Ogbu, J. U. (1987). Variability in minority school performance: A problem in search of an explanation. Anthropology \& Education Quarterly, 18(4), 312-334.

Owens, L. M., \& Ennis, C. D. (2005). The ethic of care in teaching: An overview of supportive literature. Quest, 57(4), 392-425. https://doi.org/10.1080/00336297. 2005.10491864

Pace, J. L., \& Hemmings, A. B. (2006). Understanding classroom authority as a social construction. In J. L. Pace \& A. B. Hemmings (Eds.), Classroom authority: Theory, research, and practice (pp. 1-32). Lawrence Erlbaum. 
Patrick, H., Kaplan, A., \& Ryan, A. M. (2011). Positive classroom motivational environments: Convergence between mastery goal structure and classroom social climate. Journal of Educational Psychology, 102(2), 367-382. https://doi. org/10.1037/a0023311

Patton, M. Q. (2014). Qualitative evaluation and research methods (4th ed.). SAGE.

Peterson, E. R., Rubie-Davies, C., Osborne, D., \& Sibley, C. (2016). Teachers' explicit expectations and implicit prejudiced attitudes to educational achievement: Relations with student achievement and the ethnic achievement gap. Learning and Instruction, 42, 123-140. https://doi.org/10.1016/j.learninstruc.2016.01.010

Piaget, J. (1952). The moral judgment of the child (M. Gabain, Trans.). Collier Books. (Original work published 1932)

Piaget, J. (1981). Intelligence and affectivity (T. A. Brown \& C. E. Kaegi, Trans.). Annual Reviews.

Pillen, M. T., Den Brok, P. J., \& Beijaard, D. (2013). Profiles and change in beginning teachers' professional identity tensions. Teaching and Teacher Education, 34, 86-97. https://doi.org/10.1016/j.tate.2013.04.003

Rodriguez, D. (2008). The usual suspect: Negotiating White student resistance and teacher authority in a predominantly White classroom. Cultural Studies/Critical Methodologies, 9(4), 483-508.

Rogoff, B. (2003). The cultural nature of human development. Oxford University Press.

Roithmayr, D. (1999). Introduction to critical race theory in educational research and praxis. In L. Parker, D. Deyhle, \& S. Villenas (Eds.), Race is . . r race isn't: Critical race theory and qualitative studies in education (pp. 1-6). Westview.

Rubin, K. H., Bukowski, W., \& Parker, J. (2006). Peer interactions, relationships, and groups. In N. Eisenberg (Ed.), Handbook of child psychology: Social, emotional, and personality development (6th ed., pp. 571-645). Wiley.

Sadker, M., \& Sadker, D. (1994). Failing at fairness. Touchstone.

Saldaña, J. (2012). The coding manual for qualitative researchers. SAGE.

Schulz, R., Schroeder, D., \& Brody, C. M. (1997). Collaborative narrative inquiry: Fidelity and the ethics of caring in teacher research. International Journal of Qualitative Studies in Education, 10(4), 473-485. https://doi. org/10.1080/095183997237052

Simson, D. (2014). Exclusion, punishment, racism, and our schools: A critical race theory perspective on school discipline. UCLA Law Review, 61, 506-563.

Sleeter, C. E. (2017). Critical race theory and the Whiteness of teacher education. Urban Education, 52(2), 155-169. https://doi.org/10.1177/0042085916668957

Spilt, J. L., Koomen, H. M., \& Thijs, J. T. (2011). Teacher wellbeing: The importance of teacher-student relationships. Educational Psychology Review, 23(4), 457-477. https://doi.org/10.1007/s10648-011-9170-y

Stake, R. E. (1995). The art of case study research. SAGE.

Tufford, L., \& Newman, P. (2012). Bracketing in qualitative research. Qualitative Social Work, 11(1), 80-96. https://doi.org/10.1177/1473325010368316

U.S. Department of Education, National Center for Education Statistics. (2018). The condition of education 2018. https://nces.ed.gov/pubs2018/2018144.pdf 
van den Bergh, L., Denessen, E., Hornstra, L., Voeten, M., \& Holland, R. W. (2010). The implicit prejudiced attitudes of teachers: Relations to teacher expectations and the ethnic achievement gap. American Educational Research Journal, 47(2), 497-527. https://doi.org/10.3102/0002831209353594

van Tartwijk, J., den Brok, P., Veldman, I., \& Wubbels, T. (2009). Teachers' practical knowledge about classroom management in multicultural classrooms. Teaching and Teacher Education, 25(3), 453-460. https://doi.org/10.1016/j. tate.2008.09.005

Velasquez, A., West, R., Graham, C., \& Osguthorpe, R. (2013). Developing caring relationships in schools: A review of the research on caring and nurturing pedagogies. Review of Education, 1(2), 162-190. https://doi.org/10.1002/rev3.3014

Weinstein, C. S. (1998). "I want to be nice, but I have to be mean": Exploring prospective teachers' conceptions of caring and order. Teaching and Teacher Education, 14(2), 153-163. https://doi.org/10.1016/S0742-051X(97)00034-6

Wentzel, K. R. (1993). Does being good make the grade? Social behavior and academic competence in middle school. Journal of Educational Psychology, 85(2), 357-364. https://doi.org/10.1037/0022-0663.85.2.357

Wentzel, K. R. (2002). Are effective teachers like good parents? Teaching styles and student adjustment in early adolescence. Child Development, 73(1), 287-301. https://doi.org/10.1111/1467-8624.00406

Wentzel, K. R. (2010). Students' relationships with teachers. In J. L. Meece \& J. S. Eccles (Eds.), Handbook of research on schools, schooling, and human development (pp. 75-91). Routledge.

Westrick, J. M., \& Yuen, C. Y. M. (2007). The intercultural sensitivity of secondary teachers in Hong Kong: A comparative study with implications for professional development. Intercultural Education, 18(2), 129-145.

Williford, A. P., Maier, M. F., Downer, J. T., Pianta, R. C., \& Howes, C. (2013). Understanding how children's engagement and teachers' interactions combine to predict school readiness. Journal of Applied Developmental Psychology, 34(6), 299-309. https://doi.org/10.1016/j.appdev.2013.05.002

Wubbels, T., \& Brekelmans, M. (2005). Two decades of research on teacher-student relationships in class. International Journal of Educational Research, 43(1), 6-24. https://doi.org/10.1016/j.ijer.2006.03.003

Yin, R. (1994). Case study research: Design and methods. SAGE.

\section{Author Biography}

Shannon Audley is an associate professor of Education and Child Study at Smith College. Her research research examines (in)justice in schools, focusing on understanding how youth and their teachers think about, experience, and respond to instances of (in)justice within the school context. In particular, she is interested understanding the forms and functions of (dis)respect in hierarchical and egalitarian relationships in the school setting, and how youth position and negotiate their social identities (e.g. gender, ethnicity) to serve as both as risk and resiliency factors in their interactions within schools. 